\title{
A QUARTER CENTURY OF NATO-RUSSIA RELATIONS
}

\author{
Raluca Iulia Iulian 1
}

\begin{abstract}
After the end of the Cold War, in the new international context, two important actors emerged on the international scene, namely NATO and the Russian Federation. The cooperation between them was a necessity to ensure and strengthen a climate of security and peace in Europe and all over the world. In the new challenges of the security environment, NATO was turned from a purely defensive military alliance for Europe into a political and military alliance that can act wherever needed around the globe. The Russian Federation, the successor of the former USSR and inheritor of its military arsenal, has initiated a transition process towards democracy and market economy. Russia has acted permanently to establish a special relationship with the Alliance, different from that with the other Central and Eastern European countries. The relations NATO-Russia followed a continuous development from 1991 to 2008, with periods of crisis, but hopes of establishing a productive partnership. Then, they went into decline, and in April 2014 they were suspended. The Alliance and Russia have different views on European and global security issues. After 25 years of NATO-Russia relations, this paper aims to point out the main aspects of the stages from 1991 until now and analyze the reasons why the collaboration is not yet productive and cooperative, as shown by recent events.
\end{abstract}

UDC Classification: 327.5; DOI: http://dx.doi.org/10.12955/cbup.v5.998

Keywords: European security and stability, NATO-Russia cooperation, institutional structures.

\section{Introduction}

The political events that took place during the period 1989-1991 have led to profound political changes in Europe, which have radically improved the security environment with consequences at European and global level. The Berlin Wall fell on 9 November 1989 and Germany has been united. On March 3, 1991, the Warsaw Pact ceased to exist and was formally dissolved at the Prague meeting on July 1, 1991. On June 28, 1991, the Council for Mutual Economic Assistance was dissolved too. During 1989 the communist regimes collapsed in Central and Eastern Europe. Moscow's former satellite states have initiated profound economic, political and social transformations. On December 26, 1991, the dissolution of the USSR (Union of Soviet Socialist Republics) took place. Its former satellites have fully regained their sovereignty. Fifteen ex-Soviet republics appeared, along which the largest, which was the Russian Federation or Russia. They had undergone a radical change.

26 years ago, the heads of states of the two Cold War superpowers - the Soviet Union and the United States - Mikhail Gorbachev and Donald Regan, expressed the bilateral willingness of cooperation in the new international context. During the London Summit of 15-16 July 1991, the two heads of states declared their intention to establish a Soviet-American partnership that represents the end of the Cold War. The basis of this partnership was the Soviet-American cooperation during the war in the Middle East (1990-1991).

After the breakup of the Soviet Union, the cooperation between NATO (North Atlantic Treaty Organization) and Russia began. The collaboration between them knew several stages, and different forms of collaboration were created. In time a special relationship had been realized between NATO and Russia. It has experienced periods of development and periods of crisis.

After 25 years of NATO-Russia relations, this paper aims to point out the main aspects of the stages from 1991 until now and analyze the reasons why the collaboration is not yet productive and cooperative, as shown by recent events.

Perceived as a paradox because the confrontation between the United States and the Soviet Union defined the Cold War period, the cooperation between NATO and Russia - the opponents in the Cold War - occupies a predominant place in the evolution of the security environment since 1991 to date. The collapse of the Soviet bloc and the dismantling of the USSR constituted the most influential events of contemporary history. At that moment, the two important actors in International Politics emerged: NATO and Rusia. In the framework of the Alliance, the United States carries the weight and possess the important nuclear potential. The Russian Federation is the political and military heir of the former USSR, owning of the nuclear arsenal of the Soviet Union.

\footnotetext{
${ }^{1}$ University Politehnica of Bucharest, iri_2015@yahoo.ro
} 


\section{NATO after the Cold War}

In the international context of the post-Cold War period, the Alliance initiated a transformation process to adapt to the Europe's new security situation. At the Summit meeting in London (5-6 July 1990) the heads of states and governments of NATO members decided to adopt the Alliance to the new international situation. For this purpose, a New Strategic Concept has been elaborated to respond to the new risks and challenges. It was adopted at the NATO Summit held in Rome on 7-8 November 1991. Unlike previous concepts, the New Strategic Concept emphasized the cooperation with former adversaries instead of confrontation but added the specific obligation to work towards extending and strengthening security throughout Europe. The New Strategic Concept was based on the principles of cooperation and multidimensional security. The enlargement of the Alliance by the integration of the former communist countries became a priority after 1991 for increasing the area of stability, security, and democracy in Europe. The U.S.A. and its Western Allies expressed the desire to transform NATO into a strategic alliance covering the whole Europe (The Alliance's New Strategic Concept, 1991). During the history, Europe has been confronted with many wars. The goal was to ensure security and stability in the Euro-Atlantic area and beyond.

The area of intervention of the Alliance was extended outside Europe, anywhere in the world where action is needed. Because the threats came not only from Europe but had a global character, it was necessary to restructure NATO and transform it from a military alliance into a political and military alliance, reflecting a new balance between Europe and North America. After the end of the Cold War, the main security threats were the proliferation of weapons of mass destruction, terrorism and organized crime. These new threats are complex and have two dimensions: civil and military. The Alliance had to adapt its policies and institutions in order to meet the new threats of the contemporary world. In these conditions, NATO has been restructured, thus it diversified its attributions, multiplied and diversified its functions. It has emerged as a stronger security and defense organization.

The Strategic Concept adopted at the NATO Summit in Lisbon on 10-20 November 2010 provides the main lines of action of the Alliance for the next decade. The summit was dominated by two major events: the military operations in Afghanistan and a new approach to the relations between the Alliance and Russia. For the first time, an official document of the Alliance stated that Russia is not an enemy and that NATO is a partner for stability and security and a common space of security and stability should be created in which Russia should participate. Regarding the relations between Alliance and Russia, NATO Secretary General Anders Fogh Rasmussen expressed his desire to see progress in cooperation in three directions, which he considers essential to build confidence between allies and Russia: missile defense, conventional arms control and reducing of short range nuclear weapons (Lisbon Summit Declaration, 2010, para. 23).

Nowadays, NATO has to respond to the new challenges enumerated above, but also to the ,increasing confidence of Russia in its forces, the country that does not hesitate to use the force to defend their interests against its neighbors", as affirmed the chief of Czech diplomacy, Karel Schwarzenberg, 10 years after the admission of the Czech Republic to NATO (as cited in Mihăescu, 2009).

\section{Russia after the breakup of the USSR}

The Russian Federation, internationally recognized as the successor state of the Soviet Union, heir to its military arsenal, after 1991 experienced a decline in its regional and global influence. In internal politics, it experienced the transition from imperial status to post-imperial status. The Soviet Union was a superpower, one of the two superpowers during the Cold War. After 1991 Russia represented a powerful country, with an important nuclear military potential. Russia kept the atomic arsenal of the former USSR completely and continued the position of the Soviet Union as a nuclear power in the world, with a capacity comparable to that of the U.S.A. In the first years after 1991 it was considered a secondary power pole.

After the end of the Cold War, Russia experienced a period of political and economic transition from centralized economy to market economy, from totalitarianism to democracy. From the economic point of view, some effects of the Cold War led to a stagnant Russian economy and unemployment. During and after the disintegration of the Soviet Union, wide-ranging reforms including privatization and market and trade liberalization were undertaken, including the radical changes along the lines of „shock therapy” recommended by the World Bank and the International Monetary Fund. The result 
was a major economic crisis, characterized by a 50\% decline in both Gross Domestic Product (GDP) and industrial output between 1990 and 1995 (Glenn, 1996).

The territory of Russian Federation is about $17,000 \mathrm{~km}^{2}$ out of $23,000 \mathrm{~km}^{2}$ which represent the territory of the former USSR. It remained, however ,, geographical superpower, stretching across 11 time zones, from the southern Baltic coast to the Bering Strait (...) essential to the international system by virtue of its unique geographic position in Eurasia" (Trenin, 2002, pp. 20 and 29). Although it experienced a territorial decrease, Russia is the largest country in the world. In terms of its population, it is currently only the ninth country in the world. At the census of December 2010, Russia's population was 142,905,200 inhabitants (Terzi, 2011). As Trenin notes „Today's Russia encompasses just about 50 percent of the Soviet population, 60 percent of its industrial capacity, and 70 percent of the land mass. The latter is of key importance" (Trenin, 2002, p.12).

Although Russia cannot be confused with the USSR in size, population and especially as the military and political power, most of its leaders, regardless the political party to which they belonged, did not accept that Rusia is a secondary and limited regional power and continued to believe in its great power status. In all administrations of Presidents Yeltsin and Putin ,efforts have been made to develop what may be called multi-directional influence: that is, to balance relations with the U.S.A. and Western European states by fostering strategic partnerships" (Smith, 2006, p. 39). Consequently, Russia experienced a consolidation process gradually after 2000, especially in the first decade of the 21st century. This decade represents an important stage in Russian history because it regained the status of great power in Europe and all over the world. From this moment Russia began to reaffirm in international relations, in world politics. These circumstances have led to the shaping of a special relationship of cooperation between Russia and the NATO.

President Putin expressed the intention that Russia reaches the international status of the ex-USSR and maintains control of the former republics of the Soviet Union. Since the collapse of the USSR, Russia continued to pay special attention to the territories that were part of the Soviet Union. The Russian doctrine is founded on the term near abroad (Russian: ближнее зарубежье, blizhneye zarubezhye).

In the National Security Strategy of Russia, NATO is still perceived as an opponent. According to the document approved by the Kremlin in 2009, the NATO expansion is seen as a threat to the Russian national security. It reaffirms Russia's right to use nuclear weapons if the state is threatened. Russia's new military doctrine shows that the expansion of NATO into Eastern Europe is the „main external threat that could lead to an armed confrontation” (Russia's National Security Strategy, 2009).

\section{NATO-Russia cooperation forms}

The first step in the evolution of NATO-Russia relations is represented by the "Message from Turnberry" (Scotland), initiated by the governments of NATO members in June 1990. In July 1990 at the NATO Summit in London, offers of friendship and cooperation have been made to the Soviet Union and other countries in Central and Eastern Europe. For this purpose, the contacts with the governments, leaders, and representatives of the Soviet Union and of the ex-communist countries who were invited to NATO Headquarters in Brussels have been established. The bilateral relations have been developed between Moscow and Brussels. NATO Secretary General visited Moscow immediately after the London Summit to „transmit to the Soviet leadership the proposals contained in the Declaration and the decision of the Alliance to constructively use the emergence of new political opportunities" (NATO Handbook, 2001, p.38). An important step was the announcement made by President Gorbachev in July 1990, concerning the acceptance of the inclusion of the East Germany in the Alliance, after the unification.

In 19-21 November 1990 in Paris was adopted the Charter of Paris for a New Europe (Paris Charter) by European governments in addition to those of Canada, the United States, and the Soviet Union. The charter is a common non-aggression commitment, established on the foundation of the Helsinki Accords, and further amended in the 1999 Charter for European Security. Together, these documents form the agreed basis for the Organization for Security and Cooperation in Europe (OSCE).

After the dissolution of the USSR, NATO and Russia begun to develop relations which evolved and were institutionalized in time. NATO took the initiative to get closer to Russia and the states of Central and Eastern Europe, former members of the communist bloc and former NATO adversaries. In the conditions of the transformation of NATO into a political and military organization and redefining 
the role of NATO in post-Cold War era, Russia was looking to establish a special relationship with the Alliance, different from that of the other Central and Eastern Europe countries. The special relationship was justified by its economic and military weight and by its nuclear potential.

Since 1991 until now, several forms of collaboration have been established between the Alliance and the Russian Federation. They have gradually increased in complexity: North Atlantic Cooperation Council (NACC) was created on December 20, 1991 renamed Euro-Atlantic Partnership Council (EAPC), in 1997, Partnership for Peace (PfP) created in 1994 and perfected as a Partnership for Peace Intensified and More Operational in 1999, in which Russia has an equal position like the excommunist countries of Central and Eastern Europe. By the Founding Act on Relations, Cooperation and Mutual Security between NATO and Russian Federation signed on May 27, 1997, the Permanent Joint Council (PJC) was created. It marks the beginning of the NATO-Russia special relations. It was replaced by NATO-Russia Council (NRC) on May 28, 2002.

The creation of NRC represented the realization of a new stage in the relations between the Alliance and Russia. This represents the highly evolved form of cooperation between NATO and Russia until this moment. In this structure, Russia has an equal position to other members and shares the same responsibilities (Danilov, 2013). However, Russia does not have the veto right concerning the decisions of the Alliance, although constantly it acted to get it. The NRC did not bring anything new regarding the security relations between NATO and Russia. The article 5 of the Washington Treaty was not mentioned in the founding documents of the NRC. Relations with NATO remained controversial and inconsistent. They present problems and large differences of opinion. Although there were achievements in the framework of the NRC, there is no „full transparency” between NATO and Russia (Ivanov, 2005).

Favorable proposals toward Russia conditioned the realization of NATO-Russia collaboration institutions. The PfP was signed after long-term negotiations and after concessions made to Russia (the agreement "no vetoes, no surprises"). The Founding Act (the creation of PJC) was signed in May 1997 before the NATO Summit in Madrid (July 1997). NRC was created in May 2002, after September 11 attacks, during the period of collaboration against terrorism between Russia and U.S.A.

\section{Assessment of the cooperations forms}

The relations NATO-Russia from 1991 until this moment went through several stages. During the period 1991-1993 there were consensual relations between NATO and Russia. The international events influenced the relations between them by approaching the two international actors. In the history of NATO-Russia relations, one important issue is the collaboration between them in the fight against terrorism after September 11. Other international events have disrupted the NATO-Russia relations and generated crisis.

The periods of crises usually were determined by NATO's actions that Russia did not agree with or Russia's actions that NATO did not agree with. Thus, the crisis in 1994 was caused by the decision of NATO to start the military intervention in Bosnia without consulting Moscow. In response, Russia postponed the conclusion of the adhesion document to the Partnership for Peace. In 1999, the crisis was determined by the NATO decision of March 24, 1999, to start the bombing of Yugoslavia (Kosovo) which was strongly disapproved by Russia. Another crisis between NATO and Russia was caused by the second NATO enlargement concerning the admission of the Baltic States (2004), countries that Russia considers to belong to its near abroad. Generally each NATO Enlargement toward East generated tensions in NRC. The Alliance included all the ex-Warsaw Pact members and three former Soviet republics, the Baltic countries. Russia had constantly manifested opposition against NATO Enlargement and perceived it as a threat to its national security. According to the Russia Security Strategy ,the post-Soviet geographic area should be recognized as Russia's exclusive sphere of influence" (Margarete Klein, 2014). Gordon Hendrickson, attaché of the US Embassy in Moscow, expressed his conviction that „Russia cannot content to look at the NATO expansion Eastward without taking attitude" (Hendrickson, 2006).

The Russia's attitude depended on its economic and political development. In the first years after the breakup of the USSR Russia was weak compared to the Soviet Union. The period 2000-2008 represents the economic and political upswing of Russia as a result of the economic and political reforms proposed and put in action during Putin mandates. 
Regarding the West, during the first years of collaboration, the Allies presumed that Russia is a country in crisis after the breakup of the Soviet Union. Consequently, they took important decisions without taking into account Russia's opinion: the military intervention in Bosnia, the NATO bombing of Yugoslavia (Kosovo). These actions sparked discontent of Russia and perturbed their relations. Moscow perceived the establishment of the missile defense shields in its proximity as a violation of agreements made in 1997. According to these agreements, there were not supposed to be important military bases on the territory of the new member states, in the proximity of Russia.

Since 1991 the West has been divided. After the end of the Cold War, the divergences between NATO members became deeper. Therefore, concerning the enlargement process, in time, different positions appeared. The Summit in Madrid (8-9 July 1997) was consensual; there were no divergences between NATO members. At the Prague Summit (21-22 November 2002) there were some hesitations of Germany concerning the admission of the Baltic States. At the Bucharest Summit (2-4 April 2008) the European NATO members were divided for economic reasons and presented opposing points of view concerning the adhesion of Georgia and Ukraine. The division of European NATO members influenced the relations between the Alliance and Russia and gave Russia the possibility of imposing in international politics.

The Russo-Georgian war (August 2008) represented an important moment in NATO-Russia relations. In March 2008, after the unilateral declaration of independence of Kosovo, Putin said that its recognition "undoubtedly fired up separatism and presents a very dangerous precedent" (Putin: Recognition of Kosovo, 2008). This was used as a justification for military actions in 2008 and 2014. The Russia's actions: the Russo-Georgian war (2008), the annexation of Crimea and the conflict in Eastern Ukraine (2014), which followed after the secession of the provinces Donetsk and Luhansk determined opposition of NATO and the international community. The Ukraine conflict generated the strongest crisis in NATO-Russia relations until now.

Compared to the previous crises which were brief and did not lead to the total interruption of the relations, this crisis led to the interruption of the NRC activity on April 1, 2014, and created suspicion between the two partners. Three NRC meetings took place in 2016, but they did not bring anything new. The NRC did not begin the activity yet. Russia and NATO kept only the diplomatic and military contacts.

\section{Conclusion}

The NATO-Russia relations presented a predictable evolution after the creation of PJC and NRC. Each attempt to get closer to one another was ended with crises followed by a cooling-freezing period, then another period of improvement, then another crisis. The NATO-Russia relationship has not been consolidated and strengthened in time although there were initial prerequisites for this.

NATO and Russia have different views on European and global security issues. After the Cold War, the Alliance initiated an Enlargement to the East for extending democracy, security, and stability in Europe. Russia has perceived the enlargement of NATO as a threat to its national security. It considers that the OSCE has to be the main entity in charge of European security and that NATO should be subordinated to OSCE. Russia considers that it deserves to have the veto right concerning the Alliance's decisions. NATO could not accept this because it contravenes the basic principles of the Founding Act. In these conditions, Russia believes that the West did not behave as expected.

Taking into account the fact that NATO and Russia were rivals during the Cold War, approximately a half of century, the creation and institutionalization of relations between them represent important accomplishments for the European and global security and stability. This represents an inedited collaboration between the most powerful military alliance that existed during history and the largest country in the world. Despite the different perceptions and misunderstandings, the beginning of the collaboration between the two rivals of the Cold War represents an important achievement for the European security and stability. The forms of collaborations that have been created can evaluate in time and develop a framework for global peace and prosperity. 


\section{References}

Danilov, D. (2013, July 9). Russia - NATO: Strategic Partnership Dilemmas. Russian International Affairs Council. Retrieved from http://russiancouncil.ru/en/inner/?id_4=2088\#top-content

Glenn E. C. (1996). Economic Conditions in Mid-1996. Russia: A Country Study. Washington: GPO for the Library of Congress, 1996. Retrieved from http://countrystudies.us/russia/58.htm

Hendrickson, G. B. (2005, December). The future of the NATO-Russian relations: Or, How to Dance with a Bear and Not Get Mauled. The Occasional Paper. Washington D.C. The Atlantic Council of the U.S. Retrieved from http://www.atlanticcouncil.org/images/files/publication_pdfs/82/0512-

Future_NATO_Russian_Relations_Gordon_Hendrickson.pdf

http://rustrans.wikidot.com/russia-s-national-security-strategy-to-2020

Ivanov, S. (2005, Winter). Maturing partnership. Sergei Ivanov analyses the evolution of NATO-Russian relations since the creation of the NATO-Russia Council from Moscow's perspective. NATO Review. Retrieved from http://www.nato.int/docu/review/2005/Middle-East/Maturing-Partnership/EN/index.htm

Klein, M. \& Kaim, M. (2014, October). NATO-Russia relations after the Newport Summit. SWP Comments 41. German Institute for International and Security Affairs. Retrived from https://www.swpberlin.org/fileadmin/contents/products/comments/2014C41_kim_kle.pdf

Lisbon Summit Declaration in the meeting of the North Atlantic Council in Lisbon. (2010, November 20). NATO Official Texts . Retrived from http://www.nato.int/cps/en/natohq/official_texts_68828.htm

Mihăescu, M. (2009, Mars 12). Increderea tot mai mare a Rusiei în forțele proprii este o provocare pentru NATO [Russia's growing confidence in their own abilities is a challenge for NATO]. Retrieved from http://www.hotnews.ro/arhiva/2009-03$12 / 3$

NATO Textbook (Manualul NATO). (2001). NATO - 1110 Brussels: Office of Information and Press. Retrieved from http://www.clr.ro/menu1/manualul\%20nato.pdf

Putin: Recognition of Kosovo was a very dangerous precedent. (2008, March 10). Kosovo Compromise. Retrived from http://www.kosovocompromise.com/cms/item/topic/en.html?view=story\&id=670

Russia's National Security Strategy to 2020. (2009, May 12). Retrieved from

Smith, A.M. (2006). NATO Russia Relations Since 1991: From Cold War Through Cold Peace to Partnership?. New York, NY: Routledge.

Terzi, A. (2011, Mars 29). Moscova în faţa crizei politice şi demografice (Moscow in front of the political and demographic crisis), Karadeniz Press. Retrieved from http://karadeniz-press.ro/kara/tag/crizei-politice/

The Alliance's New Strategic Concept. (1991, November 7-8). NATO Official Texts. Retrived from http://www.nato.int/cps/en/natohq/official_texts_23847.htm

Trenin, D. (2002). The End of Eurasia: Russia on the Border Between Geopolitics and Globalization. Washington D.C.: Carnegie Endowment for International Peace. 